University of Louisville

ThinkIR: The University of Louisville's Institutional Repository

Faculty Scholarship

$6-2002$

\title{
English only and U.S. college composition.
}

Bruce Horner

University of Louisville, horner.bruce@gmail.com

John Trimbur

Follow this and additional works at: https://ir.library.louisville.edu/faculty

Part of the English Language and Literature Commons, and the Rhetoric and Composition Commons

\section{Original Publication Information}

This article was originally published in College Composition and Communication, volume 53, issue 4, in June 2002.

This Article is brought to you for free and open access by ThinkIR: The University of Louisville's Institutional Repository. It has been accepted for inclusion in Faculty Scholarship by an authorized administrator of ThinkIR: The University of Louisville's Institutional Repository. For more information, please contact thinkir@louisville.edu. 
Bruce Horner

John Trimbur

\section{English Only and U.S. College Composition}

In this article, we identify in the formation of U.S. college composition courses a tacit policy of English monolingualism based on a chain of reifications of languages and social identity. We show this policy continuing in assumptions underlying arguments for and against English Only legislation and basic writers. And we call for an internationalist perspective on written English in relation to other languages and the dynamics of globalization.

$\mathbf{T}_{\mathrm{r}}$ he fact that U.S. writing instruction is conducted in English seems commonsensical. After all, though English is not the official language of the U.S., this is an English-speaking nation. As everyone from politicians and educational policymakers to non-English speaking immigrants knows, in the U.S., a knowledge of English is virtually required to get an education, to develop professionally, and to participate in civic life. As a consequence, a first-year course in written English, along with basic writing and ESL courses that point students toward fluency in written and spoken English, seems not only to make sense but to be inevitable in the design of writing programs and curriculum.

The purpose of this essay is to raise some questions about this familiar state of affairs. We argue that a tacit language policy of unidirectional English monolingualism has shaped the historical formation of U.S. writing instruction and continues to influence its theory and practice in shadowy, largely

CCC 53:4 / JUNE 2002 
unexamined ways. We are aware that for many writing teachers the very notion of language policy is likely to call up images of English Only legislation, debates about Ebonics, and the phonics wars-issues to take a position on by voting, lobbying, and calling on our professional associations to use their powers of influence in public forums. To say the first-year writing course actually embodies a language policy that privileges English in relation to other languages may sound, in the first instance, either far-fetched or simply a statement of the obvious terms that define our work. We can imagine readers asking how it could be otherwise. For this reason, we want to make clear at the outset that we are not quarreling with the fact that writing instruction in college composition courses takes place in English. Instead we want to examine the sense of inevitability that makes it so difficult to imagine writing instruction in any language other than English. As we hope to show, a tacit language policy of unidirectional monolingualism has a history and a cultural logic that have gone largely unacknowledged in our field and that, by remaining unexamined, continues to exert a powerful influence on our teaching, our writing programs, and our impact on U.S. culture.

Histories of rhetoric and composition as an academic discipline typically consider the field's intellectual affiliations and professional identities in relation to English studies, on one hand, and to speech communication, on the other, with virtually no attention to the relation of writing instruction to modern languages other than English. Writing instruction in the modern university, as many have noted, was institutionalized in the late-nineteenth and early-twentieth centuries as part of a larger modernizing initiative to replace the classical curriculum of the old-time pietistic college with a secular education in the vernacular. The question for the modernizers, as Theodore W. Hunt put it in 1884, was, "Will the classics as taught in our colleges make any concessions of their large amount of time to the modern languages?" (121). For compositionists, the history of these turf fights for space in university curricula is often invested with nostalgic regrets for the decline of rhetorical education and yet, at the same time, approval of the modernizers' struggles against the stultifying practice of teaching Greek and Latin as "mental discipline" and the restrictive premises of its underlying faculty psychology.

What has been neglected, in our view, is that the final defeat of the ancients by the moderns institutionalized not only a required first-year course in written English but also a language policy that replaced the bilingualism (in principle if not always in practice) of the classical curriculum with a unidirectional monolingualism. We are certainly not defending the justly discredited 
oral recitations and "translation English" of the classical curriculum, but we want to call attention to the fact that the triumph of the vernacular dramatically rearranged the relationships among languages and the roles they were slotted to play in the curriculum. After overturning the classical curriculum, the victorious moderns had, in effect, to work out a postwar settlement that allotted spheres of influence to the modern languages. As we will see, a "territorialization" of the modern languages separated them into departmentsdistinct academic entities defined by their national borders-where French, German, Spanish, and Italian took their place in the curriculum as reading courses to study national literatures and cultures, while English alone was assigned the task of writing instruction.

This territorialization of the modern languages, we argue, cannot be understood simply as a recognition of inevitable linguistic differences that account for the present configuration of the curriculum. Our task, as we see it, is to examine the history of the inevitable and to identify the cultural logics that produce it. In the most general sense, the settlement arranged by the moderns can be seen in terms of a chain of reifications that has settled into our own contemporary beliefs and practices as writing teachers. By "reification," we mean the treatment of something, such as spoken and written language, that is always in process, located in and subject to ongoing and varying material practice, as a fixed, idealized entity removed from the vagaries of time, place, and use. In this regard, reification is what makes things seem inevitable, givens by the fact of their being instead of their history. Here are the links in the chain of reification. First, the territorialization of languages according to national borders puts into place a reification of social identity in terms of language use: one's social identity is defined in terms of nationality, which itself is defined in terms of a single language. Next, language use itself is reified and identified with a reification of language, located most commonly in writing, so that the variety, range, and shifting nature of language in use are reduced and restricted to the canons of "proper usage" embodied in standard written English. Finally, and of great relevance to writing teachers, these reifications are used to locate individual learners on a sequence of development fixed in its order, direction, and sociopolitical significance.

This chain of reifications inflects our work as writing teachers in consequential and sometimes unsuspected ways. Our argument in the following sections has two main parts. First, we show how the tacit language policy of unidirectional monolingualism took root in the late-nineteenth century in the very formation of the U.S. first-year writing course by characterizing the other 
modern languages as national literatures to be read and studied but not written or spoken. ${ }^{1}$ Second, we demonstrate the pervasiveness of a tacit unidirectional, monolingual language policy by showing how it operates today in parallel ways in debate over English Only legislation and beginning college-writing students. The pervasiveness of this tacit policy extends to recent debates in ESL scholarship on relationships among languages and between languages and social identity. Though a full discussion of these debates is well beyond the scope of this essay, we find them apposite to any rethinking of both English Only policies and the tacit monolingualism of U.S. college composition.

As might be expected, the assumptions of a unidirectional monolingual policy are rampant in arguments advocating English Only legislation and in views hostile to beginning college-writing stu- We pose an alternative way of thinking about composition dents. More troubling is programs, the language of our students, and our own language the fact that these as- practices that holds monolingualism itself to be a problem and a sumptions, as we show, limitation of U.S. culture and that argues for the benefits of an are also prevalent in ar- actively multilingual language policy. guments against English

Only and for the interests of beginning college writing students, as well as in arguments for and against ESL. While political expediency may, at times, justify these latter arguments, we question the long-term consequences of such accommodationist rhetoric. Against such a stance, we pose an alternative way of thinking about composition programs, the language of our students, and our own language practices that holds monolingualism itself to be a problem and a limitation of U.S. culture and that argues for the benefits of an actively multilingual language policy.

\section{Language policy in the formation of the modern curriculum}

The displacement of the classical languages that made room in the curriculum for the modern languages and writing instruction in the vernacular resulted from a protracted struggle more than from a single decisive battle. By 1885, when Adams Sherman Hill succeeded in institutionalizing the first-year course at Harvard, the traditional authority of the classical curriculum had already seriously eroded. As S. Michael Halloran points out, as early as the mid-eighteenth century at Harvard, English had started to replace Latin in disputations and orations, and while at first only the dullest students composed in English, eventually the brightest were doing so as well. Moreover, before the Civil War, "scientific schools" such as Sheffield at Yale, Lawrence at 
Harvard, and the Massachusetts Institute of Technology granted bachelor of science and bachelor of philosophy degrees that dispensed with either Greek or both Greek and Latin as graduation requirements. In fact, by the turn of the previous century, as Laurence R. Veysey notes, "the practice of granting separate degrees ... for students who lacked a background in the classics began to disappear at most major universities" (118), and many colleges and universities had abolished altogether both entrance requirements in the classical languages and required course work for graduation.

The story of how the required first-year writing course fits into the modernization of the university curriculum has been told many times before. Understandably, the interest of composition historians such as James A. Berlin, John Brereton, Robert J. Connors, Sharon Crowley, and Susan Miller has been to explain the low status of writing instruction in the modern university. The formation of the first-year course at Harvard looms emblematically in this regard. Both Hill and the four reports of the Harvard Committee on Composition and Rhetoric in the 1890s sought to establish entering students' poor preparation in written English as the grounds for a required first-year course and a downward pressure on Harvard's feeder schools to increase attention to instruction in written English. While this line of reasoning certainly helps explain why first-year English has such an ambiguous academic status, defined not so much as part of the college curriculum as a stop-gap measure until the secondary schools improved their students' preparation in writing, it was not the only means of arguing for space in the curriculum. Conservative Yale, for example, took the opposite tack from Harvard, arguing in its 1900-01 Annual Report that it was the achievement of students interested in written English, rather than their poor preparation, that justified more space in the curriculum. Two years before required Greek was abolished at Yale, we can see the rationale for a new allotment of space in the curriculum being put in place:

Among all college studies the one which most steadily grows in public favor is English.... It is chosen by students of the higher classes in constantly increasing numbers; and what is perhaps most important of all, its serious study outside the classroom is increasing year by year. The formation of reading clubs, the active competition for places in the college periodicals, and the increased excellence of the student work which finds its way into these periodicals, are all evidences of a general trend. (qtd. in Veysey 234, emphasis added)

But whatever arguments were made for assigning more space in the curriculum to course work in written English, the abolition of requirements in Greek and Latin marked a decisive shift away from the traditional claim of the 
old-time college system that the study of the classical languages provided students with cultural literacy, mental discipline, and the ability to write and speak well in English. Consequently, the deployment of language in undergraduate education changed in two major respects. First, the classical curriculum's predominantly oral and performative pedagogy of classroom recitation and rhetoricals, or exhibitions of public oratory, was replaced by an emphasis on such now standard literate practices as lectures (delivered from written texts) and student production of written texts (e.g., daily themes, note taking in lectures, written examinations, lab reports, abstracts, research papers). Second, the relationships among languages were rearranged. English was separated altogether from Greek and Latin as the vehicle of writing instruction, and the modern languages settled into their respective departments as national literatures. We look at each of these changes in turn.

The oral recitations of the classical curriculum offered an especially inviting target for the scorn of the modernizers. Recitations, to be sure, tended to be dull and mechanical exercises, as the following well-known passage by Lyman H. Bagg demonstrates. At Yale in the 1860s, Bagg says,

In a Latin or Greek recitation one may be asked to read or scan a short passage, another to translate it, a third to answer questions as to its construction, and so on.... The reciter is expected simply to answer the questions which are put to him, but not to ask any of his instructor, or dispute his assertions. (qtd. in Russell 39)

To the contemporary observer, it is no wonder, as Edward E. Hale put it, that the "classical men made us hate Latin and Greek" (qtd. in Graff 19). Moreover, as Charles Francis Adams argues in his 1883 Phi Beta Kappa address, "A College Fetich," there is little relation in the oral recitations between means and ends and no substance to the classical theory that "a knowledge of Greek grammar, and the having puzzled through the Anabasis and three books of the Iliad, infuses into the boy's nature the imperceptible spirit of Greek literature, which will appear in the results of his subsequent work, just as manure, spread upon a field, appears in the crop which that field bears" (qtd. in Graff 30).

This relation of means and ends, or what the modernizers considered to be a lack of connection between oral recitation in Greek and Latin and the ability to write in English, is taken up in the Harvard Reports, where Adams appears again, along with E. L. Godkin and others, as one of the modernizing authors appointed by President Charles Eliot. Not surprisingly, the First Report (1892) attacks explicitly the long held theory that "the proper way to learn to write English is to translate orally Greek or Latin" (Brereton 93), and the 
Second Report (1895) presents a brief experiment that challenges the connection between translating Greek and Latin and the ability to compose in English. While the Fourth Report (1897) concedes the potential value of translating Greek and Latin into written English, the traditional oral method of language learning is characterized as "slovenly," "slip-shod," and "inexact," producing only "that lazy, mongrel dialect "Translation English"

The assumption resounds throughout the Harvard Reports that the proper preparation for the "advanced work" in college is mastery of written English.
(Brereton 114). Despite the gesture toward the bilingualism of the older curriculum - and the explicit approval of the educational value of students' moving between languages by translating Greek and Latin into English - the real solution, as far as the authors are concerned, is to make more time in elementary and secondary education for instruction in written English and to replace the daily oral recitations in all classes with regular written exercises. The assumption resounds throughout the Harvard Reports that the proper preparation for the "advanced work" in college is mastery of written English. The authors quote tellingly as a typical statement of the problem the remark by an entering Harvard student: "I believe that I received [in preparatory school] far too little training in writing English, for my own good" (Brereton 117).

The issues raised in the modernizers' attacks on the recitations of the classical curriculum go well beyond the matter of identifying effective means of language learning. The moderns' characterization of the recitation as what John Franklin Genung called "a most grateful refuge to dull and perfunctory teachers" (Brereton 139) has a certain formulaic and stereotypical quality which suggests that profoundly different orientations toward language divided the modernizers of vernacular literacy from the "classical men" of the older oratorical tradition. David Russell's more balanced appraisal of the classical curriculum indicates, for example, counter to the findings of the Harvard Reports, that while the "recitation and the rhetoricals were almost always oral, they necessitated much writing as preparation for speaking" (38). Indeed, in Russell's view, the interaction of oral and written modes created a particularly languagerich environment:

If much of the speaking and writing in recitation classes was highly structured, it was at least structured to include many kinds of activities: oral reading, notetaking on spoken and written material, translation, paraphrase, historical and philosophical commentary. Students not only manipulated language (and languages) they did so in progressively more sophisticated ways throughout their schooling, leading up to full-blown public speaking and debate. In the 1870s reci- 
tation would suffer wide attack for its sterility, routine, and lack of motivation. But in the hands of skillful teachers (and there were some), recitation was a flexible instrument for gradually developing the linguistic and, with it, intellectual facility that students needed to enter positions of authority in an oral, face-toface culture. (40)

As Russell makes clear, the gap between the ancients and the moderns is a cultural as much as a pedagogical one-a matter of a perceived epochal and generational shift from the older nineteenth-century oratorical culture to the print culture of the modern age. According to the Fourth Harvard Report, the "old generation - the masters of the old school ... could only in rare individual instances adapt themselves to the new order of things" (Brereton 124). For this reason, unsurprisingly, it "devolved" on Harvard to lead the "great change" into the modern era, aiming at "nothing less than elevating the study of English to the same plane of dignity which has for centuries been the peculiar attribute of the classical tongues" (Brereton 125). To put it another way, by discrediting the older oratorical tradition and the classical curriculum's belief that the study of Greek and Latin offered an effective means of learning to write in English, the modernizers at Harvard shifted the terms of work from the movement among languages to writing instruction in English only. In an important sense, the language policy of the modern university begins to emerge

The language policy of the modern university begins to emerge in recognizable form as writing in English is severed from its former association with the classical languages.

in recognizable form as writing in English is severed from its former association with the classical languages.

And this shift, in turn, is linked to the second major change in literacy education we have already noted. With the abolition of Greek and Latin requirements, the modernization of the university not only sealed the fate of the classical curriculum and the older oratorical tradition, it also created a moment of flux in which the linguistic terrain of the curriculum appeared, at least briefly, to be up for grabs. That is, to consolidate the triumph of the vernacular, the modernizers needed to reach a settlement among the modern languages by assigning them their cultural roles and spaces in the curriculum.

This territorialization of the modern languages has its own peculiar history. The Smith Chair in French and Spanish, for example, had been established at Harvard in 1816, and by 1872, just three years after Eliot arrived at Harvard, there were already departments of English, French, German, and Spanish. Still, it was not immediately agreed upon what languages should be counted as modern in the college curriculum. As Wallace Douglas observes, the "origi- 
nal staples of modern language study were modern only in the sense that they were not classical, ... 'fundamental courses' such as Old and Middle English, Old Norse, Old French, Old High German, and the like" (48). Nor was it necessarily clear whether the modern languages constituted one field or many and how time should be allotted to each. As late as 1901, nearly thirty years after departments of English, German, French, Italian, and Spanish had been established at Harvard, President Eliot still referred to the modern languages, in his welcoming address to the annual MLA convention, as a single division of knowledge within the university rather than separate departments. Earlier, in the first volume of PMLA (1884-85), Theodore W. Hunt, one of the foremost advocates of an enlarged share of the curriculum for English, divided the curriculum into "the three great departments of Science, Philosophy, and Language and Literature" (118), recommending that the one-third time allotted to language and literature be divided equally among the major languages-Latin, Greek, French, German, and English (with English getting its fifth).

\section{English was elevated to preeminent status in the curriculum, and the other modern languages were, in effect, assigned their limited spheres of influence, territorialized as national literatures in their separate departments, where students encountered them as texts to be read, not living languages to be written or spoken.}

Nonetheless, Hunt's plea for an "equitable regime," where languages and literatures joined together in the curriculum "on a common ground and for a common end" (122), largely went unheard. The experience at Harvard, once again, is suggestive. In 1894, the only two courses required of all students were first-year English and a modern language. By 1897, however, the only requirement was the first-year English writing course. Instead of the increased "prominence" Hunt had recommended for English, English was elevated to preeminent status in the curriculum, and the other modern languages were, in effect, assigned their limited spheres of influence, territorialized as national literatures in their separate departments, where students encountered them as texts to be read, not living languages to be written or spoken.

This settlement of the modern curriculum, as we have already indicated, has been largely overlooked in composition histories of the first-year course. This oversight, in turn, obscures the outlines of the language policy that has long guided institutional practice in the first-year course and in the relations among the modern languages. For not only did the monolingual emphasis on written English replace the implicit bilingualism of the classical curriculum's emphasis on translation, the territorialization of the modern languages as read- 
ing courses assigned the status of a living language to English only, making it alone the primary vehicle of instruction in writing and speaking. If, in retrospect, this territorialization appears to be inevitable, we now need to consider how this sense of inevitability was articulated and codified as a standard feature of the modern curriculum. During the first two decades of the Modern Language Association, from its formation in 1883 to 1902, when PMLA discontinued the "Pedagogical Section" in the journal, there was a good deal of pedagogical and curricular discussion of both English and the other modern languages that offers important clues to how the languages were reconfigured in the curriculum following the demise of the classical curriculum. As we will see, faculty in the "foreign" languages played a crucial part in representing English as the "mother tongue" and the other modern languages as national literatures. Over this twenty-year period, we can identify four overlapping and mutually reinforcing strategic beliefs that shaped the settlement of the modern curriculum and the roles ascribed to English and the other languages.

\section{Learning the modern languages as living, spoken languages is held to be a nonintellectual, feminine activity}

The Yale Report of 1828, a defense of the classics and mental discipline against advocates of a more flexible program of undergraduate study, set the tone for many years by dismissing the modern languages as subjects "to be studied, as an accomplishment, rather than as a necessary acquisition” (qtd. in Graff 36). Viewed as a social attainment and a sign of good breeding rather than proper intellectual work, the acquisition of fluency in speaking the modern languages, especially the Romance languages, was characterized as a suspiciously effeminate activity that evoked both the supposed sensuality of the Catholic Mediterranean and the lack of seriousness associated with the female academies and boarding schools, where French, Italian, and Spanish were studied instead of the ostensibly more rigorous Greek and Latin. Along these lines, in his MLA Presidential Address of 1890, James Russell Lowell, Smith Chair of French and Spanish at Harvard, caricatured the "stray Frenchman" who, after "failing as a teacher of his mother tongue ... turned dancing master"-a "calling," Lowell says, which "public opinion seems to have put on the same intellectual level as the other" (5). Marked as both feminine and nonintellectual, the "mere fluency in speaking a language," E. H. Babbitt, professor of modern languages at Columbia, argues, "requires no higher order of intellect, and no more exercise of the judgment... than to play the banjo; and both can be learned equally well in 'six easy lessons"” (54). 


\section{The modern languages are represented not as living languages but as texts in an archive}

Babbitt's dismissal of fluency in speaking as a pedagogical goal shows the pressure to legitimize the study of the modern languages by investing it with the same kind of rigor and intellectual seriousness ascribed to study of the classics. In "How to Use Modern Languages as a Means of Mental Discipline," Babbitt says that the study of modern languages can develop the faculties of memory and judgment, just as the classical studies did, by emulating such elements of classical pedagogy as grammatical analysis, etymological identification, vocabulary development, and the appreciation of national cultures, literatures, and intellectual life. For Babbitt, a serious study of the modern languages would imitate the classic's engagement For Babbitt, a serious study of the with dead, no longer spoken languages that exist modern languages would imitate the solely in the form of written texts. It is only, Babbitt classic's engagement with dead, no says, once a "pupil has acquired a good practical longer spoken languages that exist reading knowledge" that he can "gain the same solely in the form of written texts. amount of discipline as is to be obtained from classical studies" (62).

Edward J. Joynes, professor of modern languages at University of South Carolina, is even more explicit in his argument that students should encounter the modern languages as written texts and not as living languages. The "chief object of knowing [the modern languages]," Joynes says, "is to read them" (35). To clear the ground for such textual engagements, Joynes first dismisses the idea of "learning to speak in the college classroom" as "futile," "utterly wasted" exercises (38). Then he says that not only is writing in the modern languages typically begun too early, it is also "exaggerated beyond its proper importance, as though it were an end unto itself, instead of being regardedwhat it really should be-as a help to easier and more accurate reading" (40). By the same token, W. T. Hewett, professor of German language and literature at Cornell, polarizes language study into "two methods ... a knowledge of the literature or the ability to speak" (30, emphasis added) in order to show how speaking exercises divert "valuable time which should be spent in the study of the literature" and, thereby, risk leaving the student "the proud master of a few sentences, but without any literary knowledge" (31).

As we can see, the study of the modern languages is articulated along the older premises in the classical curriculum that language study promotes mental discipline and cultural literacy. As was the case in classical studies, modern language students encountered written texts drawn from an archive of liter- 
ary language separated from the daily uses and common speech of the vernacular. In this sense, the modern languages were institutionalized not as living languages but as repositories of texts, embodied both in the pedagogical and curricular practices of reading the modern languages as national literatures and in the actual assembly of written texts into archives. The establishment of the Ticknor collection of Iberian Spanish texts from the fourteenth to the nineteenth century at the Boston Public Library-the life work of George Ticknor (1791-1871), first

The modern languages were institutionalized not as living languages but as repositories of texts, embodied both in the pedagogical and curricular practices of reading the modern languages as national literatures and in the actual assembly of written texts into archives. Smith Chair of French and Spanish at Harvard and the first American to receive a PhD degree from a German university - was indicative of this trend to see the modern languages exclusively in textual terms.

\section{The study of modern languages figures unidirectionally, not as an end in itself but as a means to mastering English}

Along with the old classical appeals to discipline and a cultivated literary sensibility, modern language study was also justified in terms of "its influence in improving the pupil's command of his own” language (Babbitt 56). As noted earlier, the "modern" languages that Douglas lists, from the philological perspective dominant at the time, take their importance in the curriculum as linguistic antecedents to English.

This rendering of modern language study into an accessory to English comes out quite clearly, for example, in Joynes's insistence that "for this American people there is only one mother tongue, to which all other languages are alike foreign, and to be studied as such, by its norms and largely, too, for its own sake" (43). Even though he recommends the activity of translation as "not only the best test of the knowledge of both idioms" but as a work of "art," "science," and even the "conscience," Joynes evades any sense of reciprocity or mutuality in the movement among languages. "It were better," he makes plain, "that our students should never know other languages than to use them to debauch their English" (43). To find their proper place in the curriculum, the modern languages must take on the role of assisting the learning of Englishthe mother tongue to which they remain alien and other.

In fact, the preeminent position of English as the end of all language study figures in the modern university as the guarantor of knowledge in all fields, the living language of the academy and the ultimate warrant of understand- 
ing. As James Morgan Hart, professor of French and German at Cornell and Cincinnati and, later, of rhetoric at Cornell, asks in his revealingly titled address to MLA, "English as a Living Language," "Are you prepared to assert that a student is adequately trained in German, let us say, when he is unable to express in English the grammatical logic of a German sentence, the relation of dative and accusative, of verb and object? Do you truly believe that a student is mastering history in its sequence of cause and effect, when he is unable to express this causal sequence in phrases that have grammatical sequence?" (xv). In this sense, English has colonized the other academic fields, including the modern languages, for, as Hart says, "defective English vitiates all work in every department" (xv).

\section{English in the U.S. is represented in geographical isolation from the other modern languages}

The subordination of the modern languages to English was reinforced by drawing linguistic borders around the continental U.S. and separating the nation's

The subordination of the modern languages to English was reinforced by drawing linguistic borders around the continental U.S. and separating the nation's English monolingualism from a polyglot Europe.

English monolingualism from a polyglot Europe. To be sure, the notion that learning to speak modern languages other than English is of some genuine practical value for commerce, diplomacy, or general culture had been acknowledged early in the nineteenth century, even by some of the classicists, as long as conversational fluency figured not as a curricular fixture but as a social attainment for those who wished or were required to travel to non-English-speaking countries. In general, however, the working assumption was that Americans, as Franklin Carter, president of Williams, says in 1886, "are not forced by geographical position ... as are the French and Germans" to acquire fluency in "at least two modern languages." After all, Carter continues, "we are three thousand miles from European culture," and, besides, "England is the country which we as a rule first visit when traveling in the old world" (4)whoever the "we" may be in this sentence. Further, Carter holds, it is "absurd ... for someone living all his life in America to spend his time in mastering conversational Russian" and "certainly true," he concludes, "that most of our graduates never visit Europe nor really need a conversational use of any modern language" (5).

Carter's view of "Modern Languages in Our Higher Institutions" is remarkable not only for the way his American exceptionalism hinges on "our" differ- 
ences from Europeans. It also serves to erase the modern languages that at the time were spoken widely within both recent immigrant and longstanding ethnic cultures in America-French, German, Spanish, Yiddish, Chinese, Italian, Polish, Hungarian, and (yes) Russian - not to mention the "foreign language" schools and presses that flourished during the nineteenth and early twentieth centuries. Moreover, as Jamie Candelaria Greene shows, even the written literate use of the Roman alphabet in North America begins not with the British colonies of the seventeenth century, where historians' Anglocentric bias has conventionally located it, but a century earlier in New Spain-and in Spanish, not English. Ironically, Carter's claim for the geographical isolation of English speakers in America appears in the same issue of PMLA that published the second in Alcee Fortier's series of three articles- "The French Language in Louisiana and the Negro-French Dialect," "French Literature in Louisiana," and "Bits of Louisiana Folklore"-along with A. Marshall Elliott's "Speech Mixture in French Canada, Indian and French." Apparently, Carter's "we” was not so removed from other language speakers as he made them out to be.

What Carter and the others we have cited (themselves mostly professors of the modern languages rather than of English) help us to see is that a unidirectional monolingual language policy that gives primacy of place to English in the modern curriculum is warranted as inevitable, not because English was the only living language available in North America but because the use of spoken and written English forms what Benedict Anderson calls an "imag-

A unidirectional monolingual language policy that gives primacy of place to English in the modern curriculum is warranted as inevitable, not because English was the only living language available in North America but because the use of spoken and written English forms what Benedict Anderson calls an "imagined community" and a sense of nationhood.

ined community" and a sense of nationhood. In relation to English, the other modern languages are unnaturalized and alien, foreign languages territorialized outside the U.S. by the borders that map the nation-states as discrete geopolitical entities and the modern languages as separate departments in the university curriculum. At the same time, this tacit language policy puts into place the chain of reifications we mentioned earlier that purifies the social identity of U.S. Americans as English speakers, privileges the use of language as written English, and then charts the pedagogical and curricular development of language as one that points inexorably toward mastery of written English.

Now, it should come as no surprise that such a language policy emerged in the modern university around the turn of the century, at the height of what 
the historian Richard Hofstadter calls the "Anglo-Saxon mystique." The modernizing wing of the old elites in Boston and New York that Eliot drew on for the Harvard Reports, along with modern language professors writing in PMLA, share the era's patrician fears of race mixing, mongrelization, and a loss of vigor among the better classes. But if the robust Teutonic roots of English were invoked to provide some measure of defense against the sensuality of the Catholic Mediterranean and the otherness of Eastern European Jews and Slavs, it is easy enough for us today to renounce the First World, great power chauvinism of the time. What takes more work, and to which we now turn in the next section, is the task of showing how assumptions about language that were institutionalized around the turn of the century, at a high tide of imperialism, colonial adventure, and overseas missionary societies, have become sedimented in the way we think about writing pedagogy and curriculum.

We do so by attending to the parallel assumptions underlying debate over English Only legislation and basic writers as well as ESL. We first identify the operation of reified notions of language and sociocultural identity where it is to be expected, in the arguments advocating English Only-the most obvious current embodiment of official monolingualism - and in underlying challenges found in debates about the academic legitimacy of first-year composition students. We then show what is more alarming: the parallel operation of these same notions in arguments made against English Only policies and for the rights of first-year composition students. Finally, we consider the implications of such parallels for our arguments and practices regarding English Only, composition instruction, and ESL.

\section{English Only, basic writing, and ESL: keeping the English in language instruction and policy}

English Only legislation has arisen as a response to immigration to the U.S., and much of the support for English Only has been fueled by xenophobia. ${ }^{2}$

The debate over English Only Indeed, the debate over English Only frequently takes frequently takes the form of a Those arguing for English Only legislation implicitly, debate over immigrants themselves. and sometimes explicitly, denounce current immigrants as a threat to the health of the nation's cultural, social, economic, and physical environment. A political advertisement funded by the American Immigration Control Foundation against current immigration policies that ran in the Des Moines Register during the 1999-2000 Iowa caucus season links language, immigrants, and culture quite explicitly. 
In the advertisement, a statement superimposed in bold white letters on a blackand-white photograph of a classroom full of children of apparently different ethnic backgrounds pledging allegiance reads, "Reciting the Pledge of Allegiance together isn't as easy as it used to be because many students can't speak English.” Below the photograph image appears the explanation:

"One nation; under God; indivisible" just doesn't work anymore. Because of mass immigration, we're becoming many nations. Under many gods. And very divided .... [S] ome [immigrants] don't even care about our heritage. So, they don't speak our language, and they create their own countries within ours.... take jobs and social services from our poorest citizens.... Expand our welfare rolls. And divide our nation. (American Immigration Control Foundation)

Similar advertisements appearing during the same period and using almost identical formatting, but with their sponsorship identified as the Federation for American Immigration Reform and two organizations named Population-Environment Balance and Negative Population Growth, blamed immigrants for suburban sprawl, environmental degradation, and the corruption of politics (see Federation for American Immigration Reform, PopulationEnvironment Balance, Negative Population Growth).

Those familiar with debates over basic writers and open-admissions students will note the parallels between the depiction of immigrants in such advertisements and representations of such students by those opposed to their admission to higher education. Borrowing on similar fears of the foreign, as a number of composition scholars have noted, those expressing opposition to the admission and teaching of beginning college-student writers traditionally excluded from college have commonly identified these students precisely as foreign - not just when referring to students who have immigrated to the U.S., or even primarily when referring to such students, but when describing students born in the U.S. whose native language is English (see, for example, Shaughnessy 2-3). Basic writers have commonly been described as immigrants and foreigners to the academy, those whose right to be there is suspect and whose presence is often seen as a threat to the culture, economy, and physical environment of the academy. Basic writers have been accused of not wanting to learn, attending classes only to stay warm, resisting assimilation to academic ways and mores, crowding out those who rightfully belong there, and taking away scarce resources from those who deserve them (see Horner, "The 'Birth"' 7-10; Lu 34-36).

More significantly, for those of us concerned with language issues, both 
debates invoke the same chain of reifications of language, sociocultural identity, language learning, and, ultimately, language learners we have seen in the formation of the language policy of the modern curriculum. In the English Only debate, we see such reifications in the clear distinctions assumed between the foreign and the native, the citizen and the immigrant, distinctions used to classify, simultaneously, both peoples and languages. The advertisement cited above exemplifies such assumptions: the possibility that the photograph depicts American citizens, not all of whom speak English, is not broached nor is the possibility that the students are Americans patriotically reciting the Pledge in some other language (as indeed occurs).

Such distinctions among and reifications of peoples, languages, and sociocultural identities ignore the fact that, for example, the social identity of immigrants can be described as in some ways in process: they are of no fixed or single national, regional, or linguistic The social identity of immigrants can be identity nor, for that matter, are those idendescribed as in some ways in process: they tified as nonimmigrants. Indeed, such disare of no fixed or single national, regional, or tinctions are arbitrary. It is not clear, for linguistic identity nor, for that matter, are example, how many years or generations those identified as nonimmigrants. must have elapsed for an individual or family to shed "immigrant" status. And it is common for individuals to move back and forth between the land of their birth and the U.S. (and vice versa) and to identify with different nations and languages at different times. For instance, in an essay on distinguishing among bilingual writers, Jan Frodesen and Norinne Starna describe "Alex," a "functional bilingual," as similar in background to many other students "whose families move back and forth between the United States and Mexico" (65). Alex, born and raised in Los Angeles with his family, moved at the age of five to Mexico with his mother and siblings for economic reasons, where he remained until age sixteen, when he returned to Los Angeles to live with his father and attend school (Frodesen and Starna 65-66). Yuet-Sim D. Chiang and Mary Schmida, in a study of how and with what consequences Asian-American students at UC Berkeley manage linguistic and cultural identity, report that students frequently "position themselves as in between worlds" (85, emphasis added). One student, for example, answered a question about being bilingual by explaining, "I'm kind of in between, I guess. I don't really speak [Chinese] that well, therefore I'm non-native Chinese. But language and culture are kind of connected, I think" (qtd. in Chiang and Schmida 86). Noting the "spectrum" of responses students give when asked to explain their native and non-native 
identification, Chiang and Schmida observe that such categories "force [students] to categorize their identity into an either-or sort of framework, when in fact they may not perceive it in such clear-cut distinctions" (90).

Chiang and Schmida conclude their study by challenging the efficacy of "clean cut categories such as mainstream English speaker, ESL speaker, or bilingual students"(91). While acknowledging that "categories like ESL, bilingual, and linguistic minority do indeed serve to delineate some students, these categories are inadequate when it comes to capturing the literacy journey of students whose lived realities often waver between cultural and linguistic borderslands" (94). However, these types of categories, based on reifications of language and identity, have dominated the way students are represented and programs institutionalized in both ESL and non-ESL college composition. Such categories, as several complain, overlook important differences among students. Linda Harklau, Kay Losey, and Meryl Siegal note, for example, that "ESL texts and curricula often contain an implicit assumption that international students are the normative population of college ESL classrooms, leading to certain suppositions concerning learners' backgrounds and skills," and overlooking the growing numbers of bi- or multilingual students raised in the U.S. ("Linguistically Diverse" 2). More generally, while careful not to deny the importance of acknowledging differences among students, scholars are increasingly questioning the validity, in both teaching and research, of categorizing students and their writing into native/non-native (Kachru, "Sources"; Leki; Sridhar; Valdés). Distinctions based on similar reifications of language and identity have operated in tracking students into basic writing courses. As David Bartholomae has observed,

As a profession, we have defined basic writing (as a form or style of writing) by looking at the writing that emerges in basic writing courses. We begin, that is, with what we have been given, and our definition is predetermined by a prior distinction, by a reflex action to sort students into two groups (groups that look "natural" or "right")... . We know who basic writers are, in other words, because they are the students in classes we label "Basic Writing." (67)

To shore up the reification of an individual's national identity against one's actual, the very notion of identity is itself tied to language (as in the injunction “Speak American!”) (Rodby 34). However, just as the identification of a nation and national identity with a single language is problematic, so the language identity of those named foreign, immigrant, or native is no more easily fixed than is their national identity (cf. Leung, Harris, and Rampton). Establishing a 
speaker's language identity is difficult for at least three reasons: first, the boundaries distinguishing the languages spoken are themselves both arbitrary and in flux (cf. Canagarajah 70-75; Rodby 33); second, the relation between the

There is, after all, no clear point at which an individual can be said to be or not to be a speaker of a given language, just as there is no clear point at which someone can be said to have achieved literacy.

speaking of a language and one's social identification is at best tenuous; and third, a speaker's language competence, for lack of a better term, is in constant flux (Spack 772; Valdés). There is, after all, no clear point at which an individual can be said to be or not to be a speaker of a given language, just as there is no clear point at which someone can be said to have achieved literacy (Valdés 102-08; Harste et al. 69). Rather, as Pierre Bourdieu observes, linguistic competence is a political judgement about legitimacy:

The competence adequate to produce sentences that are likely to be understood may be quite inadequate to produce sentences that are likely to be listened to, likely to be recognized as acceptable in all the situations in which there is occasion to speak. Here again, social acceptability is not reducible to mere grammaticality. Speakers lacking the legitimate competence are de facto excluded from the social domains in which this competence is required, or are condemned to silence. (55; cf. Schiffman 277)

And as Bartholomae has observed,

[Basic writers] are not the only ones who make mistakes and who present their work in ways that are inappropriate for a university. Mainstream freshmen, senior English majors, graduate students, our colleagues may all produce work that is naive, wrong, or off the track. The issue, then, is not who misses the mark but whose misses matter and why. To say this is to return attention to institutional processes of selection and exclusion. (68)

Hence we are hesitant to use the term competence to describe a speaker's language, since what constitutes language competence is itself arbitrary and continually subject to negotiation and redefinition.

Moreover, despite the standard hypostatization of languages by linguists, the boundaries distinguishing individual languages are at best, in Einar Haugen's term, "ragged margins" (Rodby 33; Zamel "Complicating”). What does and does not constitute English, for example, so long as it is spoken, remains subject to change, negotiation, even fracturing into different Englishes (see Canagarajah 128-29; McArthur). And finally, the speaking of a given language has no clear correspondence with how one identifies oneself, though it may be 
inappropriately used by others as a marker of one's social or cultural identity (see Spack; Zamel "Toward"). Chiang and Schmida find that "students' selfdefinition is not grounded in a clear or competent ability to speak the ethnic language; instead, it is informed by a sense of cultural identification" (85). Students "identify with their heritage language, even if they do not speak it .... It is as if by claiming the language, they claim a linguistic identity that perhaps exists in their minds, but not in their tongues" (87). Conversely, Constant Leung, Roxy Harris, and Ben Rampton suggest this last complication in noting studies that show urban youth destabilizing ethnicity through their language use, and the phenomenon of "language crossing," in which minority languages are used by ethnic "out-groups" (e.g., Panjabi spoken by African-Caribbean Britishers) (Leung et al. 548; see also Canagarajah 74-76 and studies cited there). A similar complication to linking language to national identity is suggested by the indigenization of English in a host of postcolonial polities to the point where English has come to be understood not as a foreign but a second or native language (Canagarajah 4, 129; Kachru Alchemy; Nayar 11).

In an apparent concession to this state of flux in language and social identity, a process of language learning is sometimes acknowledged; however, that process is imagined to develop in a fixed sequence leading, again, to an ideal, arbitrarily defined competence (Canagarajah 128; Kachru "Sources"; Sridhar). This idealized competence is often linked, again, with a distinct national identity: legally, for example, a specific competence in English is required to be granted U.S. citizenship. In what appears to be a further concession to the possibility of someone speaking a range of languages, at least in some arguments of those advocating English Only legislation, it is claimed that restrictions are to be placed only on written language or language for official occasions, meaning effectually language based in writing, whatever the medium of delivery, and not on private speech. ${ }^{3}$ Thus, in these arguments, writing, not spoken practice, is viewed as the codification of the official language, the one that counts.

This privileging of writing as the embodiment of the standard against which other uses

This privileging of writing as the
embodiment of the standard against
which other uses of language are judged
marks the point where the teaching of
writing and the debate over language
legislation most clearly intersect.
of language are judged marks the point where the teaching of writing and the debate over language legislation most clearly intersect. Moreover, in debates over the place of composition students in the academy, we can see comparable reifications of social identity, tied to language use; reifications of language 
itself, linked to writing; and the assumption of a fixed sequence of language development moving toward an ideal state of competence. We have already noted the common identification of certain groups of native-born U.S. students as foreigners to the academy in public and scholarly discourse on composition students. Such identifications use instances of these students' written language to mark them as belonging outside the academy, foreign to its ways. Significantly, that outsider status is based on the assumption of the fixed state of their language: the language evidenced in an instance of their writing, as in a written placement essay exam, is taken as evidence of their language use as a whole, which is assumed to be fixed and uniform.

Further, just as in the English Only debates, the boundaries separating one language from another are imagined as fixed, so in representations of students, the language of the academy is seen as discrete from the language of the outside, associated with students' home neighborhoods or ethnic, class, and racial identities. Finally, the composition course, or a fixed sequence of required writing courses, is charged with moving students/foreigners to the academy toward that ideal state of competence in academic English writing through a predetermined set of stages of writing development (cf. Rodby 19; Horner "Mapping" 117-25). Writing itself, like language, is understood in reified form, rather than as a set of heterogeneous and shifting practices.

Again, these parallels are perhaps most obvious, perhaps too obvious, in arguments for English Only and in arguments opposed or hostile to the admission of some students, such as those labeled basic writers, and opposed to granting the academic credit to college composition courses for these students on the grounds that the work accomplished in such courses is at best preparatory, rather than integral, to academic work generally. What we wish to address now is the degree to which that same set of parallel assumptions operates in arguments opposed to English Only and for the rights of beginning college composition students. ${ }^{4}$ Many arguments opposing English Only legislation make the point that such legislation is unnecessary because (1) immigrants are already learning English as fast as, if not faster than, immigrants in the past, and so clearly show an awareness of the importance of knowing the language; and (2) English Only legislation ignores the difficulty of learning a second language, characteristically making no provision for helping immigrants to learn English, and so would leave many immigrants in the lurch (see, e.g., Nicolau and Valdivieso; Crawford "What's Behind" 175-77; Fishman 167). Thus, the arguments go, English Only legislation is offensive in its assumption that immigrants are so ignorant as not to be aware of the value of English, when 
they clearly are aware of it, and it is insensitive in failing to recognize the difficulty of learning English and in failing to assist immigrants in doing so. It is also argued that such legislation, far from providing a means of preventing cultural divisions, is itself divisive in offending and insulting immigrants.

Given current political exigencies, we are not about to forswear these arguments as unimportant. And we are certainly willing to stand behind their validity. Significant and credible evidence shows that immigrants to the U.S. are aware of the importance of English fluency and are attempting to achieve it, and that language legislation like English Only has, globally and historically, always had the effect of producing and reinforcing, rather than ameliorating, cultural strife. ${ }^{5}$ Nonetheless, such arguments leave unchallenged several of the key assumptions made by those arguing for English Only.

First, and most damagingly, the legitimacy of a primarily monolingual culture is generally accepted (Schiffman 269; cf. Nayar 12, n. 2). Learning, maintaining, or increasing knowledge of a second language is often encouraged primarily as a means of improving one's knowledge of English. For example, in an eerie echo of E. H. Babbitt's recommendation that English-speaking students study the modern languages as a means of improving their command of English, the National Council of Teachers of English 1997 Resolution on Developing and Maintaining Fluency in More Than One Language opens its argument by observing that "Literacy transfers across languages. Current research confirms the fact that English language learners acquire English more easily if they are literate in their native language."

In public debate over English Only, few arguments are made for the legitimacy of speaking languages other than English. At best, as in the nineteenth century, multilingualism is encouraged for the economic, trade advantages it may give states or businesses. In these arguments, what Judith Rodby terms a universalist understanding of languages, including English, is assumed: that is, languages are equated with currency (31). In such arguments, the nature of each language is assumed to be fixed, and what language is to be used is determined according to instrumentalist concerns, in terms of its exchange value. Unfortunately, this same view of language is invoked by advocates of English Only: English, they sometimes observe, just happens to be the common currency of the United States (and, increasingly, the world); therefore, foreigners had better exchange their languages for ours (see U.S. English).

Of course, as Rodby observes of discussions of ESL, "most discussions incorporate terms and occasionally even conflicting conclusions" (39). Those arguing both for and against English Only frequently adopt not just universal- 
ist but what Rodby terms ethnicist approaches to language that assume a link between a reified language and reified ethnic identity (Rodby 34$).{ }^{6}$ So, for example, in arguments against English Only, multilingualism is also encouraged

In arguments opposed to English Only, the threat those advocating English Only see immigrants posing to monolingual English culture is dismissed as no threat at all: those immigrants, we are assured, are eager to become fluent monolingual English speakers just like we are, their language differences something that, with time and patience and training, will disappear. as a way of preserving ethnic diversity, on the assumption that language is the primary bond and reliable cue to ethnicity (cf. Montaner 164). Unfortunately, this assumption plays into the hands of those arguing for English Only, who, no less contradictory than their opponents, herald English as the only means of ensuring the unity of American culture and society (Schiffman 271-72), an argument invoked in the advertisement cited above.

But more commonly, in arguments opposed to English Only, the threat those advocating English Only see immigrants posing to monolingual English culture is dismissed as no threat at all: those immigrants, we are assured, are eager to become fluent monolingual English speakers just like we are, their language differences something that, with time and patience and training, will disappear (see, for example, American Civil Liberties Union). For example, the Conference on College Composition and Communication statement supporting its 1988 resolution on a National Language Policy explains that English Only is unnecessary because

English, the global lingua franca and the language of wider communication in this country, is not threatened. For two centuries, most immigrants learned English within a generation without any laws compelling them. Current immigrants are doing the same.

While there is substantial evidence that this is true (see Veltman Language Shift, The Future), we question whether such an ideal should remain uncritiqued or form the guiding assumption of U.S. writing instruction.

Second, and in line with this, the status of English itself as a fixed entity to be acquired or not remains in place. As linguists have long recognized, the boundaries and, for that matter, the interior of the linguistic territory known as English are subject to change so long as it remains in use. That this is the historical norm, however, is ignored in claims that encounters with other language practices will not change what people think of as English. Located in actual practice, what is called English inevitably adjusts to changing circum- 
stance (see Leung et al. 548; McArthur). Located, however, in the realm of the ideal associated with proper English and with writing, English either remains inviolable, in the arguments against English Only, or, in arguments for it, is at risk, either of disappearing altogether or of being debauched, as Edward Joynes worried about long ago in proscribing instruction in speaking, as opposed to reading, foreign languages. ${ }^{7}$

Third, in many of the arguments against as well as for English Only, it is assumed as an ideal a single direction for language learning: by immigrants only, moving toward competence in English (Crawford Hold 206-07, 256-57; Schiffman 269; Zamel "Complicating"). Aside from ignoring variations and fluctuations in English and the concomitant arbitrariness of defining competence in it, these arguments identify the problem strictly as a deficit of immigrants and differ only in how to address that deficit, rather than seeing the difficulties faced in encounters with new immigrants as providing evidence of the limitations of the monolingualism of U.S. culture. This assumption is perhaps most tellingly revealed in the labels ESL uses to name its students and their languages. For example, as Ruth Spack has noted, terms like "foreign," "inter-

These arguments identify the problem strictly as a deficit of immigrants and differ only in how to address that deficit, rather than seeing the difficulties faced in encounters with new immigrants as providing evidence of the limitations of the monolingualism of U.S. culture.

national," and "other" used to identify ESL students assume specific sociocultural identities for the students and their languages and posit English, and English speakers, as "the norm against which the other, the different, is measured" (766; for responses to and replies from Spack, see Nelson et al.). Like the term "immigrant," such labels, while at times benign and even useful, can also be problematic, misleading, even politically noxious.

Fourth, in line with this acceptance of monolingual, reified English as the norm, it's often accepted that possession of the English language by itself accounts for the socioeconomic status of ethnic groups (Fishman 168-70; Schiffman 271-72). This is the assumption behind an Iowa state legislator's claim, in arguing for English Only legislation, that " $[t]$ he unwritten message that [the bill] sends is, 'to realize the American dream you need to speak English"' ("English Language Bill OK'd"). But it is also the assumption opponents bank on when calling, instead, for increased funding for ESL instruction, a fact that has led proponents of English Only legislation in Iowa, for example, to cleverly link such legislation with bills offering token support for such instruction (see "Immigrants' English, Welcome Centers Eyed"). ${ }^{8}$ In other words, 
the focus on language ignores the degree to which language in and of itself provides no guarantee of socioeconomic advancement, operating instead in contingent relation to a host of other factors-

The focus on language ignores the degree to which language in and of itself provides no guarantee of socioeconomic advancement, operating instead in contingent relation to a host of other factors - such as race, ethnicity, gender, class, and age - in determining one's economic position. such as race, ethnicity, gender, class, and agein determining one's economic position.

Finally, in keeping with a reified view of language, the material costs of achieving a multilingual, as opposed to an accommodationist monolingual, society are downplayed. Because English Only advocates often portray immigrants as a drain on the economy-demanding health and social services, schooling, jobs, translations, housing - those opposed have denied any costs associated with the presence of non-English speakers. They emphasize, instead, that immigrants pay far more in taxes and contribute far more to the economy than they receive in benefits, and they point to the insignificance of the costs of providing translations of government documents and the like (see, for example, American Civil Liberties Union; Crawford "Canard"). Again, while we agree with this latter cost-benefit assessment, it sidesteps the more significant costs and even more significant benefits, both economic and cultural, associated with pursuit of an actively bi- or multilingual policy, such as English Plus. ${ }^{9}$ If the aim of English Only advocates, however mean and misguided, is to protect the cultural status quo of the U.S., we should be wary of accommodating that aim in our arguments opposing such a strategy. We should refuse to accept the notion that present-day U.S. culture does not need to change, and won't be for the better, by different speakers, thinkers, and writers speaking, thinking, and writing differently.

\section{Beyond English Only}

If we are right about the limitations of those arguing against English Only in the assumptions they share with their opponents, then it behooves us to consider the possibility of parallel limitations in how compositionists think of and argue for their students and courses. For one thing, as several compositionists have argued, representations of students have been limited in problematic ways. While describing students as foreigners to the academy may have sometimes assuaged critics by assuring them that students' language differences were not evidence of cognitive deficiencies, such representations have also ignored the ways in which neither students nor teachers have ever been either fully at home 
in, or isolated from and foreign to, the academy (Horner "Mapping"; Soliday "The Politics of Difference"; Spack 766). As Mary Soliday has argued, "If we assume only an oppositional difference between us (the academy) and them (culturally different students), we limit the possibilities for complex relationships and various kinds of journeys for individual students." Thus, such assumptions might blind us to the identification she reports students making of "a strong continuity among themselves, their experiences, and the university" (“Politics" 270).

Reified notions of students' cultural identities and language habits have also misled teachers into attributing to the influence of a particular foreign culture particular writing practices. Ilona Leki, in an essay exploring the limitations of contrastive-rhetoric study for understanding second-language writing, warns that "the findings of contrastive-rhetoric research on a single text type (or a small number of text types) have sometimes been promulgated as discoveries about an entire cultural group's general rhetorical preferences" (236). Such overgeneralizations are especially troubling, Leki says, when much of this research bases its claims about rhetorical preferences on students' writing in a sec-

While describing students as foreigners to the academy may have sometimes assuaged critics by assuring them that students' language differences were not evidence of cognitive deficiencies, such representations have also ignored the ways in which neither students nor teachers have ever been either fully at home in, or isolated from and foreign to, the academy. ond language. "Imagine," she suggests, compositionists accepting "descriptions of English rhetorical patterns based on essays by a randomly selected group of NES [native English-speaking] freshmen writing in a language other than English" (236). While Leki defends studying difference for demonstrating the relativity of cultural norms, she notes that "it can also lead to regressive and limiting, even blinding, stereotypes and unwarranted categorical distinctions among groups" (241).

Such categorizing can also lead us to overlook direct and indirect interaction between cultures. Spack, for example, reports one researcher thinking "that the 'flowery effusions' in [a student's] writing were the product of the rhetorical traditions of [the student's] 'native' Afghani culture," but later found that they "were actually the result of [the student's] imitation of the style of the Harlequin romances she was fond of reading" (Spack 772). As Vivian Zamel observes, reified notions of students' cultural identities and language practices reinforce the idea "that each [language and culture] is separate from, even in opposition to, the other and keeps educators from understanding the com- 
plex ways in which the two intersect, mingle with, and give shape to one another." Thus they encourage "a deterministic stance and deficit orientation as to what students can accomplish in English" ("Toward" 341).

Moreover, an emphasis on the foreign character of students' language has sometimes led not simply to believing in but to attempting to teach a reified

While Bartholomae was being ironic in suggesting that students needed to "invent" the university in their writing, there is a real sense in which students, like all the rest of us writers, do participate in re-inventing - not simply reproducing but potentially altering —university language in each act of writing. version of academic language at odds with its heterogeneity, fluctuating character, and negotiability. As Zamel has observed of ESL scholarship, the construction of both students' and academic culture as "discrete, discontinuous, and predicable-colors both the ways in which we view our students and the academic wor(l)ds [sic] they will encounter" ("Toward" 343). While Bartholomae was being ironic in suggesting that students needed to "invent" the university in their writing, there is a real sense in which students, like all the rest of us writers, do participate in re-inventing - not simply reproducing but potentially alteringuniversity language in each act of writing. As Rodby has put it in arguing for ESL writers, "the writer has not only the ability but the right to do unheard of things with [English]" (47; see also Canagarajah 168-69, 175).

If we grant that definitions of academic discourse and competence in it are arbitrary, then the notion of leading students through a fixed developmental sequence of stages to mastery of that language has to be rethought. While different writing courses may well appropriately focus on different aspects of all that goes into writing and different writing practices, recognition of the heterogeneity and fluctuating nature of writing, including what's called academic writing, requires that we incorporate attention to such heterogeneity and fluctuation in how we design both individual writing courses and curricular programs. Relatedly, recognition of the arbitrary and fluctuating character of writing at particular sites, including the academic, requires that we reject denials of the legitimate place of students and their work in the academy, manifested in the refusal to grant academic credit for basic writing courses and the treatment of composition courses generally as, at best, preparatory to rather than an integral part of academic work. If we reject the reification of academic language and competence in it, we cannot use instances of students' language to deny them academic citizenship. This doesn't mean the abolition of standards but the development, by students and teachers working together, of dif- 
ferent standards, understood as contingent, local, and negotiable (cf. Boomer et al.; Fox ch. 4).

Just as in debating English Only we should not shy from confronting the material and cultural costs, and even greater benefits, of pursuing a multilingual ideal, so we should be wary of denying the material costs to the academy of pursuing the ideals we have for our composition programs. Highlighting such costs has usually been one of the chief strategies of those opposed to such programs, particularly basic writing programs, as justification for their elimination or downsizing. Such arguments assume that the integrity of the academy has already been achieved and is being threatened by such programs. But if we are to take academic mission statements at their word, we might argue that the costs of composition programs, far from threatening academic integrity, are crucial to achieving that as yet unrealized integrity. Certainly, any substantial writing program, whether basic writing or the universally required freshman composition course or some other version, can reasonably be understood to affect the work of its institution. But justifications for such programs usually define their role as strictly supplementary or preparatory to normal academic work. These justifications thus render the programs vulnerable to charges that they are remedial-efforts at mopping up after the failures of secondary schools

We might argue that composition courses and programs provide crucial opportunities for rethinking writing in the academy and elsewhere: spaces and times for students and teachers both to rethink what academic work might mean and be-who is and should be involved, the forms that work might take, the ends it might pursue, the practices that define it and which might be redefined.

- and, hence, that they deserve to be continually underfunded as inessential temporary add-ons. Moreover, these arguments leave unchallenged the legitimacy of the existing work of the academy as something simply to be supplemented or prepared for, rather than something in dire need of change (Horner "The 'Birth"' 6-11, 16-18).

Alternatively, we might argue that composition courses and programs provide crucial opportunities for rethinking writing in the academy and elsewhere: spaces and times for students and teachers both to rethink what academic work might mean and be-who is and should be involved, the forms that work might take, the ends it might pursue, the practices that define it and which might be redefined (cf. Brannon; Trimbur). The incorporation of service learning into composition courses obviously represents one movement in this 
direction, as it redefines the normal mode and purpose and practices for academic work by students, teachers, even administrators. More generally, such a justification for composition would place it at the academy's center, necessary to enabling the academy to achieve its heralded ideals of student-centered, interdisciplinary learning, training for responsible citizenship, service, and the like, and, as such, deserving of increased funding and support. And as several writers have suggested, we might call on our most immediately accessible constituents, the students, for support in arguing for their own centrality (Horner "Traditions" 393-94; Soliday "Class" 739; Thompson A23).

As other writers have argued, the institutional, pedagogical, and research relationships among college composition, ESL, and other language instruction need to be rethought (see, for example, Matsuda; Muchiri et al.; Silva et al.; Valdés). For those of us who identify ourselves primarily as compositionists, this means first and foremost acknowledging the degree to which our field and our pedagogy are rooted in and tacitly perpetuate a policy of English Only

Compositionists must learn to resist thinking of identifying students and our teaching in terms of fixed categories of language, language ability, and social identity, however natural and inevitable such categories can seem to be in our day-to-day work and in the arguments we make to the public in defense of our work. and the assumptions underlying English Only in much of its research, pedagogy, and institutional arrangements. In addition to broadening the range of scholarship on which they draw in thinking about their work, compositionists need to recognize the limitations of the prevailing disciplinary division of labor Paul Kei Matsuda identifies between composition and ESL in meeting the needs and building on the strengths of both composition and ESL students (see Matsuda; Matsuda and Silva). More broadly, compositionists must learn to resist thinking of identifying students and our teaching in terms of fixed categories of language, language ability, and social identity, however natural and inevitable such categories can seem to be in our day-to-day work and in the arguments we make to the public in defense of our work.

Finally, we should consider how writing programs can encourage writing in languages other than English. We might, for example, begin a dialogue with teachers of the other modern languages to identify shared concerns as well as differences in language pedagogy. And, where it makes sense, we should draw on students' interests and existing linguistic resources to design bilingual programs of study that seek to develop students' fluency in more than one written 
language and the possibilities of moving between the modern languages (Trimbur).

\section{Whose English, whose interests?}

We are, of course, trading here in ideals, and for care in how we define ideals, in our arguments about both language legislation and composition. In doing so, we don't mean to deny the significance of local historically and institutionally immediate circumstances in determining what is politically appropriate to a particular argument, or set of institutional arrangements, made in a particular set of circumstances. Nonetheless, we would urge that it is appropriate, as we make our arguments, to keep in mind the larger ideals at which we (and our opponents) aim and the assumptions we may advance in the name of politics, and that we beware of the long-term political consequences of making those assumptions for ourselves, our neighbors, and our students.

In making the case for such long-term ideals, we can benefit not only from considering the limited assumptions on which our opponents base their arguments and on which, as we have shown, compositionists themselves have sometimes relied, but also from an understanding of composition's tacit monolingual, English Only policy as an historical development. What seems both natural and inevitable must be understood instead as historical and, therefore, both the product of human agents and something subject to change. In fact, as we have shown, the historical formation of the first-year composition course is tied in tightly to a monolingual and unidirectional language policy that makes English the vehicle of writing instruction in the modern curriculum. The fact that this seems inevitable only serves to legitimate the tacit language policy.

As we have argued, this tacit language policy weighs heavily on our work studying and teaching writing. This largely unexamined language policy has made it difficult to see that U.S. college composition, from its formation to the present day, operates for the most part within national borders, at worst justifying writing instruction for reasons of economic productivity, cultural integration, and now perhaps homeland security, while at best imagining a more inclusive, pluricultural, and participatory civic life in the U.S. There is little question in our minds that U.S. college composition today is more cosmopolitan than it was, say, twenty years ago, not to mention one hundred years ago when it figured unequivocally as nationalistic instruction in an unquestioned mother tongue. There are cross-cultural and multicultural readers, syllabi with 
discussions of globalization, and a growing interest in how writing is taught in other countries. Still, as our review of the English Only debate indicates, despite this worldliness, many of the most progressive perspectives in composition studies locate the problem of English squarely within the confines of the United States. The task, as we see it, is to develop an internationalist perspective capable of understanding the study and teaching of written English in relation to other languages and to the dynamics of globalization. At a point when many North Americans hold it self-evident that English is already or about to be the global lingua franca, we need to ask some serious questions about the underlying sense of inevitability in this belief-and about whose English and whose interests it serves.

\section{Notes}

1. The history of language teaching is long, complicated, and evenly documented. In 25 Centuries of Language Teaching, Louis G. Kelly argues that pedagogical approaches have veered back and forth between "formalism" and "activism" depending on the relative emphases placed on the three main objectives of language learning-communication, literary appreciation, and philosophical (i.e., linguistic) analysis. In the early-nineteenth century, the first two holders of the Smith Chair of French and Spanish at Harvard, George Ticknor and Henry Wadsworth Longfellow, treated the modern languages as living ones and, therefore, emphasized their spoken, idiomatic character. By the late-nineteenth century, however, the balance in U.S. college language teaching had clearly tilted toward the traditional grammar-translation model, largely ignoring or being unaware of the "direct method" proposed by reformers in France and Germany and the work of linguists such as Henry Sweet, Otto Jespersen, and Harold A. Palmer in the U.K. (see Stern 75-116; Titone; Van Essen). As late as 1929, the now infamous Coleman Report, in presenting the findings of the Modern Foreign Language Study, recommended that the main goal of language learning should be reading fluency. It was not until the postwar period that secondary and college language teaching uniformly shifted to audiolingual, immersion, and other "activist" methods of learning. This shift is conventionally attributed to the response to Sputnik in 1957 and the National Defense Education Act of 1958, but, as Roger A. Pillet points out, the Modern Language Association had already initiated programs, funded by the Rockefeller Foundation from 195258 , to improve language instruction.

2. While proponents of English Only insist that they are calling not to restrict language use to English but to make English the official language of the United States, the efforts of the organizations supporting official English to ban bilingual educa- 
tion and to ban other languages from advertising, menus, radio and television broadcasts, books on the shelves of public libraries, and even telephone bills persuade us to continue to designate the policy as one of English Only. For an analysis of organizations that support making English the official language of the U.S. and their underlying motives, see Crawford "What's Behind." In our discussion of assumptions about language and identity in the English Only debate and parallels in composition, we draw on Horner “"Students' Right."”

3. English Only legislation introduced in the state of Iowa, for example, states, "The official language of the state shall be the English language and all official proceedings, records, and publications shall be in the English language."

4. In light of the critique we offer, it seems appropriate to note that it applies equally to arguments made against English Only legislation by one of us in his lobbying work and that the experience of such work is part of what has prompted our critique.

5. On the desire and efforts of immigrants to the U.S. to learn English, see Crawford Hold 97; Fishman 166, 168; Nicolau and Valdivieso 318; Veltman Language Shift, The Future; American Civil Liberties Union. On the divisive effects of language legislation, see, for example, Crawford "What's Behind" 177, and Hold 108, 200-01; Draper and Jiménez 93; Horowitz 132-33; Inglehart and Woodward; Manogaran 46-47, 52-53; Tambiah 73-77.

6. We can see both approaches implicit in the Teachers of English to Speakers of Other Languages Resolution on Language Rights insistence that "all individuals have the opportunity to acquire proficiency in English while maintaining their own language and culture" (Teachers). See also the National Council of Teachers of English Resolution on English as a Second Language and Bilingual Education.

7. While debate on English Only occasionally broaches the permeability of the borders distinguishing English, or "Official English," from other languages and from expressions of unofficial language, such as "canoe," "habeus corpus," and "y'all" (see Language Loyalties 88), generally what constitutes English is assumed to be self-evident rather than subject to challenge or in need of definition.

8. James Crawford reports that many of those voting in support of English Only initiatives do so in the mistaken belief that they are supporting the provision of ESL instruction to immigrants ("What's Behind" 175).

9. English Plus policy encourages the teaching of English plus one or more additional languages to all students in the U.S. Among the many groups supporting English Plus are NCTE's Conference on College Composition and Communication, Teachers of English to Speakers of Other Languages, and the Linguistic Society of America. 


\section{Works Cited}

American Civil Liberties Union. "The Rights of Immigrants.” ACLU Briefing Paper, 1998. <http://www.aclu.org/library/ pbp20.html>

American Immigration Control Foundation. "Reciting the Pledge." Political advertisement. Des Moines Register 4 January 2000: 5A.

Anderson, Benedict. Imagined Communities: Reflections on the Origin and Spread of Nationalism. Rev. ed. London: Verso, 1991.

Babbitt, E. H. "How to Use Modern Languages as a Means of Mental Discipline.” PMLA 11 (1896): 52-63.

Bartholomae, David. "Writing on the Margins: The Concept of Literacy in Higher Education.” A Sourcebook for Basic Writing Teachers. Ed. Theresa Enos. New York: Random, 1987. 66-83.

Boomer, Garth, Nancy Lester, Cynthia Onore, and Jonathan Cook, eds. Negotiating the Curriculum: Educating for the 21st Century. London: Falmer, 1992.

Bourdieu, Pierre. Language and Symbolic Power. Ed. John B. Thompson. Trans. Gino Raymond and Matthew Adamson. Cambridge: Harvard UP, 1991.

Brannon, Lil. "Confronting the Logic of Instrumentalism: Using Rhetoric for Social Change." Conference on College Composition and Communication. Phoenix, AZ, 13 March 1997.

Brereton, John C. The Origins of Composition Studies in the American College, 1875-1925: A Documentary History. U of Pittsburgh P, 1995.

Canagarajah, A. Suresh. Resisting Linguistic Imperialism in English Teaching. Oxford: Oxford UP, 1999.
Carter, Franklin. "Study of Modern Languages in Our Higher Institutions." PMLA 2 (1887): 3-21.

Chiang, Yuet-Sim D., and Mary Schmida. "Language Identity and Language Ownership: Linguistic Conflicts of FirstYear University Writing Students.” Harklau et al. 81-96.

Conference on College Composition and Communication. National Language Policy Statement, 1988. <http:// www.ncte.org/positions/national.html>

Crawford, James. Hold Your Tongue: Bilingualism and the Politics of "English Only.” Reading: Addison-Wesley, 1992.

"Canard: 'Multilingual Government." < http://ourworld.compuserve. com/homepages/JWCRAWFORD/ can-mult.htm> 1997.

"What's Behind Official English?" Language Loyalties 171-77.

Douglas, Wallace. "Accidental Institutions: On the Origins of Modern Language Study." Criticism in the University. Ed. Gerald Graff and Reginald Gibbons. Evanston: Northwestern UP, 1985. 35-61.

Draper, Jamie B., and Martha Jiménez. “A Chronology of the Official English Movement." Excerpted from "Language Debates in the United States: A Decade in Review." EPIC Events 2.5 (1990): 1, 4, 7. Rpt. Language Loyalties 89-94.

“English Language Bill OK'd." Des Moines Register 18 March 1999: 1A.

Federation for American Immigration Reform. "Ten Virgin Acres. A Freshwater Stream. Dozens of Old-Growth Trees. What a Great Place to Build a Parking Lot for the New High-Rise." Political Advertisement. Des Moines Register 12 January 2000: 5M. 
Fishman, Joshua A. "The Displaced Anxieties of Anglo-Americans." Excerpted from “"English Only': Its Ghosts, Myths, and Dangers.” International Journal of the Sociology of Language 74 (1988): 125-40. Rpt. Language Loyalties 165-70.

Fox, Tom. Defending Access: A Critique of Standards in Higher Education. Portsmouth: Boynton/Cook Heinemann, 1999.

Frodesen, Jan, and Norinne Starna. "Distinguishing Incipient and Functional Bilingual Writers: Assessment and Instructional Insights Gained through Second-Language Writer Profiles." Harklau et al. 61-79.

Graff, Gerald. Professing Literature: An Institutional History. Chicago: U of Chicago P, 1987.

Greene, Jamie Candelaria. "Misperspectives on Literacy: A Critique of an Anglocentric Bias in Histories of American Literacy." Written Communication 11.2 (1994): 251-69.

Halloran, S. Michael. "From Rhetoric to Composition: The Teaching of Writing in America to 1900." A Short History of Writing Instruction: From Ancient Greece to Twentieth-Century America. Ed. James L. Murphy. Davis: Hermagoras, 1990. 151-82.

Harklau, Linda, Kay M. Losey, and Meryl Siegal, eds. Generation 1.5 Meets College Composition: Issues in the Teaching of Writing to U.S.-Educated Learners of ESL. Mahwah: Erlbaum, 1999.

_. "Linguistically Diverse Students and College Writing: What Is Equitable and Appropriate?” Harklau et al. 1-14.

Harste, Jerome C., Virginia A. Woodward, and Carolyn L. Burke. Language Stories $\mathcal{E}$ Literacy Lessons. Portsmouth: Heinemann, 1984.
Hart, James Morgan. "English as a Living Language.” PMLA 1 (1884-85): xi-xviii.

Hewett, W. T. “The Aims and Methods of Collegiate Instruction in Modern Languages.” PMLA 1 (1884-85): 25-36.

Hofstadter, Richard. Social Darwinism in American Thought, 1860-1915. Philadelphia: U of Pennsylvania P, 1944.

Horner, Bruce. "The 'Birth' of 'Basic Writing.” Horner and Lu 3-29.

—. "Mapping Errors and Expectations for Basic Writing: From the 'Frontier Field' to 'Border Country." Horner and Lu 117-36.

—. ' 'Students' Right,' English Only, and Re-imagining the Politics of Language." College English 63 (2001): 741-58.

_. "Traditions and Professionalization: Reconceiving Work in Composition." College Composition and Communication 51 (2000): 366-98.

Horner, Bruce, and Min-Zhan Lu. Representing the "Other": Basic Writers and the Teaching of Basic Writing. Urbana: National Council of Teachers of English, 1999.

Horowitz, Donald L. Ethnic Groups in Conflict. Berkeley: U of California P, 1985.

Hunt, Theodore W. "The Place of English in the College Curriculum.” PMLA 1 (188485): 118-132.

"Immigrants' English, Welcome Centers Eyed.” Des Moines Register 24 February 1999: 4M.

Inglehart, Ronald F., and Margaret Woodward. "Language Conflicts and Political Community." Excerpted from Comparative Studies in Society and History 10 (1967): 27-45. Rpt. Language Loyalties 410-23.

Joynes, Edward J. "Reading in Modern Language Study.” PMLA 5.2 (1890): 33-46. 
Kachru, Braj B. The Alchemy of English: The Spread, Functions, and Models of NonNative Englishes. Oxford: Pergamon, 1986.

."Monolingual Bias in SLA Research." TESOL Quarterly 28 (1994): 795-800.

Kelly, Louis G. 25 Centuries of Language Teaching: An Inquiry into the Science, Art, and Development of Language Teaching Methodology, 500 B.C.-1969. Rowley: Newbury House, 1969.

Language Loyalties: A Source Book on the Official English Controversy. Ed. James Crawford. U of Chicago P, 1992.

Leki, Ilona. "Cross-Talk: ESL Issues and Contrastive Rhetoric." Severino et al. 234-44.

Leung, Constant, Roxy Harris, and Ben Rampton. "The Idealised Native Speaker, Reified Ethnicities, and Classroom Realities." TESOL Quarterly 31.3 (1997): 543-75.

Lowell, James Russell. "Address." PMLA 5.1 (1890): 5-22.

Lu, Min-Zhan. "Conflict and Struggle: The Enemies or Preconditions of Basic Writing?” Horner and Lu 30-55.

Manogaran, Chelvadurai. Ethnic Conflict and Reconciliation in Sri Lanka. Honolulu: U of Hawaii P, 1987.

Matsuda, Paul Kei. "Composition Studies and ESL Writing: A Disciplinary Division of Labor." College Composition and Communication 50.4 (1999): 699-721.

Matsuda, Paul Kei, and Tony Silva. "CrossCultural Composition: Mediated Integration of U.S. and International Students." Composition Studies 27.1 (1999): 15-30.

McArthur, Tom. The English Languages. Cambridge UP, 1998.

Montaner, Carlos Alberto. "Talk EnglishYou Are in the United States" ["Why Fear
Spanish?"]. Miami Herald 25 April 1988: 14A. Rpt. Language Loyalties 163-65.

Muchiri, Mary N., Nshindi G. Mulamba, Greg Myers, and Deoscorous B. Ndoloi. "Importing Composition: Teaching and Researching Academic Writing beyond North America." College Composition and Communication 46.2 (1995): 175-98.

National Council of Teachers of English. Resolution on Developing and Maintaining Fluency in More Than One Language. $<$ http://www.ncte.org/resolutions/ fluency971997.html>

National Council of Teachers of English. Resolution on English as a Second Language and Bilingual Education. <http://www.ncte.org/resolutions/ bilingual821982.html>

Nayar, P. Bhaskaran. "ESL/EFL Dichotomy Today: Language Politics or Pragmatics?" TESOL Quarterly 31.1 (1997): 9-37.

Negative Population Growth. "How Do You Feel about Paving over the Amber Waves of Grain, the Purple Mountains Majesties and the Fruited Plain?" Political advertisement. Des Moines Register 4 January 2000: 6A.

Nelson, Gayle L., Ruth Spack, and Joan G. Carson. "Comments on Ruth Spack's 'The Rhetorical Construction of Multilingual Students.” TESOL Quarterly 32 (1998): 727-46.

Nicolau, Siobhan, and Rafael Valdivieso. "Spanish Language Shift: Educational Implications." Language Loyalties 317-22.

Pillet, Roger A. Foreign Language Study: Perspective and Prospect. Chicago: $\mathrm{U}$ of Chicago P, 1974.

Population-Environment Balance. "Mass Immigration Costs Taxpayers over $\$ 69$ Billion a Year. Chicken Feed Compared to the Environmental Costs." Political advertisement. Des Moines Register 3 January 2000: 6M. 
Rodby, Judith. Appropriating Literacy: Writing and Reading in English as a Second Language. Portsmouth: Boynton/ Cook, 1992.

Russell, David. Writing in the Academic Disciplines, 1870-1990. Carbondale: Southern Illinois UP, 1991.

Schiffman, Harold. Linguistic Culture and Language Policy. London: Routledge, 1996.

Severino, Carol, Juan C. Guerra, and Johnnella E. Butler, eds. Writing in Multicultural Settings. New York: Modern Language Association, 1997.

Shaughnessy, Mina P. Errors and Expectations: A Guide for the Teacher of Basic Writing. New York: Oxford UP, 1977.

Silva, Tony, Ilona Leki, and Joan Carson. "Broadening the Perspective of Mainstream Composition Studies: Some Thoughts from the Disciplinary Margins." Written Communication 14 (1997): 398-428.

Soliday, Mary. "Class Dismissed." College English 61 (1999): 731-41.

_ . "The Politics of Difference: Toward a Pedagogy of Reciprocity." Severino et al. 261-72.

Spack, Ruth. "The Rhetorical Construction of Multilingual Students." TESOL Quarterly 31 (1997): 765-74.

Sridhar, S. N. "A Reality Check for SLA Theories." TESOL Quarterly 28 (1994): 800-05.

Stern, H. H. Fundamental Concepts of Language Teaching. Oxford: Oxford UP, 1983.

Tambiah, S. J. Sri Lanka: Ethnic Fratricide and the Dismantling of Democracy. $\mathrm{U}$ of Chicago P, 1986.

Teachers of English to Speakers of Other Languages. Resolution on Language Rights [1987]. Rpt. Language Loyalties 148-49.
Thompson, Karen. “The Ultimate Working Condition: Knowing Whether You Have a Job or Not." College Composition and Communication Forum Winter 1998: A19-24.

Titone, Renzone. "History: The Nineteenth Century." Routledge Encyclopedia of Language Teaching and Learning. Ed. Michael Byram. London: Routledge, 2000. 264-270.

Trimbur, John. "The Problem of Freshman English (Only): Toward Programs of Study in Writing." WPA 22.3 (1999): 9-30.

U.S. English. "In Defense of Our Common Language." Rpt. Language Loyalties 143-47.

Valdés, Guadalupe. "Bilingual Minorities and Language Issues in Writing." Written Communication 9.1 (1992): 85-136.

Van Essen, Arthur. "History from the Reform Movement to 1945." Routledge Encyclopedia of Language Teaching and Learning. Ed. Michael Byram. London: Routledge, 2000. 270-75.

Veltman, Calvin. The Future of the Spanish Language in the United States. New York and Washington, DC: Hispanic Policy Development Project, 1988.

. Language Shift in the United States. The Hague: Mouton, 1983.

Veysey, Laurence R. The Emergence of the American University. Chicago: $\mathrm{U}$ of Chicago P, 1965.

Zamel, Vivian. "Complicating Perspectives on the Acquisition of Language and Literacy." Conference on College Composition and Communication. Minneapolis, MN, 13 April 2000.

"Toward a Model of Transculturation." TESOL Quarterly 31 (1997): 341-52. 


\section{Bruce Horner}

Bruce Horner teaches composition and composition theory at the University of Wisconsin-Milwaukee where he is professor of English. His books include Representing the "Other": Basic Writers and the Teaching of Basic Writing (NCTE 1999), co-authored with Min-Zhan Lu, and Terms of Work for Composition: A Materialist Critique (SUNY 2000), which received the W. Ross Winterowd Award for the Most Outstanding Book Published Each Year on Composition Theory.

\section{John Trimbur}

John Trimbur is professor of writing and rhetoric and director of the Technical, Scientific, and Professional Communication program at Worcester Polytechnic Institute. His recent publications include the edited collection Popular Literacy: Studies in Cultural Practices and Poetics (U of Pittsburgh P, 2001). 